\title{
The non-romantic idea of nature in African theology
}

\begin{tabular}{|c|c|}
\hline $\begin{array}{l}\text { Authors: } \\
\text { Hermen Kroes } \\
\text { Johanneke Kro } \\
\text { Kamps }^{2} \text { (D) }\end{array}$ & $\begin{array}{l}\text { bergen }^{1} \text { (D) } \\
\text { esbergen- }\end{array}$ \\
\hline $\begin{array}{l}\text { Affiliations: } \\
{ }^{1} \text { Department o } \\
\text { and Historical } \\
\text { Faculty of Thec } \\
\text { Religion, Unive } \\
\text { Pretoria, Preto } \\
\text { South Africa }\end{array}$ & $\begin{array}{l}\text { f Systematic } \\
\text { Theology, } \\
\text { logy and } \\
\text { rsity of } \\
\text { ria, }\end{array}$ \\
\hline $\begin{array}{l}{ }^{2} \text { Department o } \\
\text { Studies, Facult } \\
\text { and Religion, } \\
\text { of Pretoria, Pre } \\
\text { South Africa }\end{array}$ & $\begin{array}{l}\text { f Religion } \\
\text { y of Theology } \\
\text { Jniversity } \\
\text { toria, }\end{array}$ \\
\hline $\begin{array}{l}\text { Research Proje } \\
\text { Project Leader } \\
\text { Project Numb }\end{array}$ & $\begin{array}{l}\text { ct Registration: } \\
\text { :J. Buitendag (D) } \\
\text { er: } 2402343\end{array}$ \\
\hline $\begin{array}{l}\text { Description: } \\
\text { This research is } \\
\text { project, 'Theol } \\
\text { Nature', direct } \\
\text { Prof. Dr Johan } \\
\text { Department of } \\
\text { and Historical } \\
\text { Faculty of The } \\
\text { Religion, Unive } \\
\text { Pretoria }\end{array}$ & $\begin{array}{l}\text { s part of the } \\
\text { ogy and } \\
\text { ed by } \\
\text { Buitendag, } \\
\text { Systematic } \\
\text { Theology, } \\
\text { ology and } \\
\text { ersity of }\end{array}$ \\
\hline $\begin{array}{l}\text { Corresponding } \\
\text { Hermen Kroes } \\
\text { hermen.kroesk } \\
\text { com }\end{array}$ & $\begin{array}{l}\text { author: } \\
\text { bergen, } \\
\text { pergen@gmail. }\end{array}$ \\
\hline $\begin{array}{l}\text { Dates: } \\
\text { Received: } 16 \mathrm{~N} \\
\text { Accepted: } 12 \mathrm{~N} \\
\text { Published: } 13 \mathrm{~J}\end{array}$ & $\begin{array}{l}\text { Mar. } 2021 \\
\text { May } 2021 \\
\text { July } 2021\end{array}$ \\
\hline $\begin{array}{l}\text { How to cite th } \\
\text { Kroesbergen, } \\
\text { Kroesbergen-K } \\
\text { 'The non-roma } \\
\text { nature in Afric } \\
\text { HTS Teologiese } \\
\text { Theological St } \\
77(3) \text {, a6624. } \\
\text { org/10.4102/h }\end{array}$ & $\begin{array}{l}\text { is article: } \\
\text { t. \& } \\
\text { 'amps, J., 2021, } \\
\text { antic idea of } \\
\text { an theology', } \\
\text { Studies/ } \\
\text { udies } \\
\text { tttps://doi. } \\
\text { ts.v77i3.6624 }\end{array}$ \\
\hline Read online: & $\begin{array}{l}\text { Scan this QR } \\
\text { code with your } \\
\text { smart phone or } \\
\text { mobile device } \\
\text { to read online. }\end{array}$ \\
\hline
\end{tabular}

In many ways, the African world view and African theology are closer to nature than EuroAmerican theology is. This can be seen, for example, in its emphasis on holism and interconnectedness, and its inclination to consider all natural objects to be inhabited by the spirit world. This article argues that this closeness to nature should not be confused with a Romantic reverence for nature. Since the 19th century, Romanticism has been very influential in the Euro-American idea of nature. Nature came to be seen as something that is both good and valuable in itself. The conception of nature that is dominant in African ways of thinking is very different: nature is seen as potentially threatening and, at best, ambivalent; and respect for nature and living in balance with nature is judged by the extent to which they help humans to live successfully. In this article, a theological and philosophical clarification of these two contrasting conceptions of nature is combined with qualitative anthropological analysis of the way Zambian pastors speak about nature in their sermons. These two approaches together bring out the often-misinterpreted non-Romantic idea of nature in African theology.

Contribution: This article clarifies the important idea of nature within the context of African theology. It brings out how the meaning of holism and sacredness in African settings differs from the meaning of these ideas in Western eco-theological contexts. Hereby, it untangles important confusions in the field of eco-theology.

Keywords: nature; African theology; Romanticism; eco-theology; holism; sacredness.

'Thank you for this wonderful life, for the air to breathe. There is sun that we're enjoying. Thank you so much for the environment, the trees that we see, Lord. Thank you so much for the life that we see even in the smallest creature. We thank you for the life.' (03 May 2020, Pastor Chifundo)

\section{Introduction}

In a time of the effects of climate change hitting Africa hard, of a decrease in biodiversity, and a growing problem of pollution caused by industry and human behaviour, a focus on nature, the environment and ecology is timely and important. There is a growing body of literature that lets ecological concerns inspire theology, of which this second special collection 'Theology and Nature' in HTS Teologiese Studies/Theological Studies is an example. Several African authors point out how Christian theology could be enriched by taking a leaf from African traditions (see, e.g., Chibuye \& Buitendag 2020; Knoetze 2021).

While we support this initiative and share the concerns regarding our environment, in this article, we want to point out a confusion in the use of the idea of nature if it is applied in an African way and read with Western eyes. In the West, the idea of nature has a particular history that cannot be seen apart from a process of secularisation from the Enlightenment forward and reappraisal in the Romantic era. In Africa, nature has different connotations. The exploration of this difference is the topic of this article.

The authors' backgrounds in anthropology and Wittgensteinian philosophy, as well as the time we have spent in an African context, have made us sensitive to the changing meanings of words in different contexts. The contrast between a European and an African perspective brings out more clearly what is significant and unique in the African idea of nature. Our purpose is not to offer an African eco-theology directly, but the clarification provided here might well serve as preliminary investigation of this concept to be taken up in future African eco-theologies. The clarification we offer should be seen as prolegomena to any future African (eco-)theology, in

Copyright: (C) 2021. The Authors. Licensee: AOSIS. This work is licensed under the Creative Commons Attribution License. Note: Special Collection: Theology and Nature, sub-edited by Johan Buitendag (University of Pretoria). 
particular when such a theology is constructed in dialogue with its Western counterparts.

The idea of nature in Western and African contexts is not the same. When reading about nature in the context of African theology, one needs to be aware of which idea of nature is being applied. The main research question that we will address in this article is, 'what is the idea of nature in the context of African theology, and how does this idea differ from Western ideas of nature?' We will show that the Western idea of nature is highly determined by Romanticism, whereas the African idea of nature is primarily of a nonRomantic kind. Clarity about this distinction is essential in the understanding and moving forward of African ecotheologies.

\section{Methodology}

We base our argument on a combination of textual analysis of contemporary scholarly publications about African ecotheology, such as Magesa (2014) and Orobator (2018), and a qualitative analysis of a collection of more than 200 sermons held in the Reformed Church in Zambia (RCZ) between March and August 2020. These sermons were available online because churches had to reach out to their congregations in new ways because of the pandemic.

The RCZ is an opportune context for research like this because it is a theologically diverse church, with influences from Pentecostal theology as well as classical Reformed theology within a genuinely African context. The time of collection meant that many services addressed the coronavirus disease 2019 (COVID-19) pandemic as an important topic, but this does not mean that topics related to nature should naturally be overlooked. After all, the outbreak of the pandemic seems to be intimately related to our relationship with the environment, as the virus that is bothering us was most likely transferred to humans from animals.

The sermons were available in the public domain as live streams on Facebook and have been transcribed and coded according to their subject matter. In these texts, sections that have a connection to nature were found using a list of 59 words related to nature, natural phenomena and the environment. ${ }^{1}$ These sections were coded and subsequently analysed to distil different aspects in the meaning of the idea of nature within this African Christian context. The quotes used in this article are representative for the discussion of the topics that we focus on. We have used pseudonyms to refer to the pastors in this article.

Studying sermons in a middle-of-the-road African church provides us with a unique opportunity to investigate the way

1.The following words were on the list: wilderness, creation, creature, nature, ecology animal, plant, tree, wood, forest, stroll, green, environment, earth, water, pollution, lake, river, lake, river, rock, cosmos, mountain, landscape, progress, dominion, hunt, deforestation, habitat, sustainable, sustainability, recycle, land, bush, cattle, hil bird, sea, stream, field, game, steward, farm, season, climate, rain, sun, moon, star,
wind, storm, seed, fruit, hike, harvest, cow, beautiful, awe, majestic, pure and wind, storm, seed, fruit, hike, harvest, cow, beautiful, awe, majestic, pure and beauty.

The search function automatically included cognates such as farm, farmer and farming. in which the idea of nature is used and not used in real-life African theology, rather than guiding the answers of respondents through particular questions. How do people in the everyday context of lived African theology speak about and not speak about nature? By combining this fieldwork approach with a literature review of African theology, we are able to locate our findings within a broader conceptual framework.

Before we turn to the results of this analysis and an African idea of nature, we will start with an overview of the specific Western idea of nature.

\section{Nature(s) in Western history}

The word 'nature' is notoriously hard to define (Williams 2015:164f.). In this article, when we use the word 'nature', we mean the world of material, natural things, for which the 'environment' is a contemporary synonym. When we speak about the idea of nature, we mean the web of meanings in which this word is suspended. Identical concepts or grammars can be used to express very different beliefs (see Kroesbergen 2020). The term 'nature' evokes a range of associations and connotations. It is precisely this web of meanings that changes over time and from place to place rather than having a fixed, stable meaning. The idea of nature is socially constructed. Our idea of nature is formed by our cultural and historical context (Descola 1996:82). Some even argue that it is better to speak of the plural 'natures' instead of the singular 'nature' (Bewell 2017). As we will argue in this article, applying such a term to a different context is perilous and may lead to confusion.

In the Western context, we distinguish three defining moments in the development of the idea of nature, namely, the Enlightenment in the 17th and 18th centuries, 19th century Romanticism and a rising concern for the environment in the 20th century. According to Thomas (1984) in his seminal work Man and the Natural World, in early modern Europe and specifically Britain, human [sic] was seen as the master over nature, carrying out his God-given dominion over the natural world, making it serve human's interest. The natural world was perceived as a resource, and the things in it derived their worth from their value for human survival. This strand of thinking has by no means died out today human and economic interests still prevail over environmental concerns on many occasions - but the first change we want to discuss takes place in the period of burgeoning scientific reasoning that we call the Enlightenment period.

\section{The Enlightenment}

In the Enlightenment, scientists focused their microscopes and instruments of measurement on the natural world to discover the rules and laws to which it obeyed. Anything that happened in the world was assumed to have a cause within that world. This meant that a sharp distinction was made between the natural which obeyed the laws of nature and the supernatural which somehow escaped these laws. 
Enlightenment scepticism succeeded in closing the borders between the natural and the spiritual world. During this period, the possibility of divine intervention and other spiritual agencies started to be doubted. As the rational world view of an orderly world governed by natural laws gained ground, there was a loss of interest in experiences that seemed to be outside that natural order, regardless of whether they were miraculous or demonic.

\section{Romanticism}

After the development of this first binary opposition between the natural and the supernatural, the second defining moment we want to touch on occurred during the period of Romanticism in the 19th century. From the end of the 18th century onwards, Europe started to become industrialised. On the one hand, this entailed a process of bringing nature ever more under control of human volition. Taming nature, making it into a resource, was a necessary step towards progress and civilisation (Giddens 2009:157). On the other hand, the processes of industrialisation and urbanisation led some people to start to idealise rural life and the natural environment that came with it. To them, growing urbanisation and industrialisation unleashed anxieties: life and work in the factory-city were seen as physically and mentally unhealthy. Opposite this urban life, an idea of rural bliss was constructed. The city may mean culture, but opposite this culture stood the equally alluring force of nature. The countryside embodied the virtues of beauty, health, stability, rootedness and timelessness that were lost in the fast-paced urban world (Hutton 1999:117). For the Romanticists, nature had worth not as a resource, but in itself, in its untamed, uncivilised character. Beyond human inhabitation, the natural environment was conceptualised as sublime, mysterious and awe-inspiring, benevolent, comforting and redemptive as opposed to the new industrial and urban environment (Hutton 1999:44). Our current sympathy for nature cannot be separated from this historical development (Bewell 2017:5).

Remarkably, the already quite domesticated European of even specifically British landscapes is mainly seen as awe-inspiring: the lovely English Lake District, the majestic Welsh mountains and the rugged Scottish Highlands. In other parts of the world, nature may be sacred - like the Himalayas in Asia or the wilderness of Yellowstone in the United States - but it may also be conceptualised as dangerous. According to Bankoff (2001), a large part of the world is ideologically constructed as unsafe for Westerners because it is disease-ridden, poverty-stricken and disaster-prone. The majestic landscapes of developing countries are associated with a harsh, dry climate, dangerous game and disease-bringing insects and natural disasters such as earthquakes, volcanic eruptions and tsunamis (Bankoff 2001:20f.). This makes the idea of nature not only bound to a specific time and cultural context, but also to a geographic area.

\section{Twentieth century}

Alan Bewell (2017:3ff.) calls the contemporary world postnatural. New technologies of transportation, communication and information have brought nature closer to the urban world - even the most remote place on the planet is accessible within just a few days of travel, or immediately in your living room through a screen. On the other hand, the question is whether this nature is still natural in the sense that the Romanticists conceive it - primordial, closer to God than to human culture, a force to be reckoned with. Today, so much of nature is brought under human control that, in the words of Bewell (2017:4), such that 'it hardly seems appropriate even to call it by that name' because there is nothing natural as opposed to cultural left (see also McKibben 2007), who speaks about the end of nature.

Even if the name nature may not be appropriate any longer, a new label has come in its place. Since the 1950s, the word nature has started to be eclipsed by another term: the environment (Giddens 2009:157). Our natural environment encompasses all non-human surroundings in which human beings exist (Giddens 2009:158). The 19th-century binary opposition between nature and culture still echoes in the new idea of the environment. Rather than being evaluated as a positive force in itself, the environment is, however, mainly associated with problems such as natural disasters, pollution and climate change. Over time, nature has developed from a well-ordered resource to a place of strength and beauty to something that needs our protection more than anything. In all of these views, human beings have the prime position as users, spectators or saviours of nature (cf. Maris 2018).

To sum up this brief overview of the idea of nature, in the West, nature is associated with beauty, awe and other positive emotions. It is separated from both the supernatural and the civilised. It is also a thing that needs to be protected from the polluting influence of human civilisation. Nature may be perceived as sacred, but this sacredness is inspiring fascination more than trembling in Western humanity.

As we will argue in the following sections, this idea of nature often is present in African eco-theologies as well. However, it is hardly found in the language of ordinary Christians, for example, in the sermons of RCZ pastors in Zambia.

\section{A first glance at the idea of nature in Zambian religious language}

What is the idea of nature that speaks from the sermons of Zambian pastors? Is it similar to the Western idea of nature, which focuses on its beauty as well as its vulnerability? In the collection of sermons held in the RCZ that we have analysed, the epigraph of this article is the only quote that speaks about nature as something to be enjoyed or even revered. It is the only quote that addresses God as the creator of all life on earth and speaks about gratefulness for his creation.

Nature is not a main concern for pastors in the RCZ. Words that relate to the environment and its challenges often do not come up in the services. Ecology, pollution, deforestation, sustainable or sustainability are not mentioned at all. Even when words from our list of nature words are used, they are used in ways that do not relate to nature at all. 
Take, for example, the word 'stewardship'. In Genesis 2:15, God commands Adam to be a steward of creation. In contemporary eco-theologies, 'stewardship' is an important term to remind Christians of their responsibility to take care of the environment in a sustainable way. In the RCZ, the overarching theme of the third quarter of 2020 was Financial Stewardship. The word 'stewardship' therefore came up in quite some instances. This stewardship did entail a responsibility to care, but not for the natural environment. Pastor Timothy (19 July 2020), for example, says:

We are stewards that have been entrusted, that have been given the mandate, to use what God has given us to carry out his work. We are stewards of the body, of the lives, of the parts of the body, of the skills that he has given us, of the talents he has given us.

Here, stewardship is purely related to one's capacities, not to a responsibility for what happens around us. For Pastor Matthew (19 July 2020), stewardship extends beyond the personal. He says, ' $[a]$ responsible steward is the person committed to take care for both him and their neighbours'. Stewardship is interpreted as a responsibility for that which is in your control: for your own abilities, or even for the people in your surroundings. Nature is never mentioned as a target for stewardship.

Some contemporary eco-theologies see the use of analogies from the animal kingdom as evidence for the closeness of African people to nature. In the sermons, one animal analogy is used. Pastor Benjamin (03 May 2020) tells the following story:

I was doing a research on attitude, and in the process of my research I stumbled against somebody who said that the lion is not the strongest animal in the bush, not the largest animal in the bush, but the lion is feared by almost all the animals in the bush. He says, "The difference is that a lion has a different kind of attitude. It believes in itself. The lion has told itself that, "I am a hunter. I am a killer". So, when it sees buffaloes passing by, the lion sees food, because the lion believes it has what it takes to hurt and to kill an animal.'

The only animal analogy used in over 200 sermons is one where the lion is commended for having a killer mentality, which gives him the ability to use other animals as its resources. A love or care for nature is hard to find in this quote.

Still, we have been able to find illustrations in the sermons for two important topics that play a role in contemporary ecotheologies, namely, holism and the sacredness of nature. In the following sections, we will discuss how these illustrations are related to the theological works.

\section{Holism}

Holism is often seen as part of the solution for our contemporary ecological crisis (see Buitendag 2019:306). As acknowledged above, something has gone terribly wrong with the earth's environment. We are said to live in the Anthropocene, the current geological era in which the earth is changed dramatically by human actions. Mass extinction of species is one of the consequences of this human influence. If we want to save the world - and with it humanity itself we humans need to radically reconfigure our relationship with our ecological environment.

One way in which we can re-conceptualise our engagement with nature is the Gaia-hypothesis which is gaining traction through the work of Jürgen Moltmann (see Buitendag 2019). Introduced in the 1970s by James Lovelock, the Gaiahypothesis asks us to look at all living organisms on earth interact with the inorganic material around it in one, big, complex, self-regulating system. It has become commonplace to consider the opposition between humanity and nature as one of the underlying motives that has led to our looming ecological crisis. Once we give up contrasting culture and nature, once we start to see humanity as an integral part of nature, we may hope to avoid an ecological Armageddon, to restore Gaia to its original unity, according to the Gaiahypothesis (see Buitendag 2019).

This widely adopted Romanticist line of thinking offered an opening to philosophers, theologians and other thinkers from Africa to promote African traditional thought, as we will see. 'The world is looking for a holistic way of thinking; we already have a holistic way of thinking!' is often declared triumphantly in scholarship on Africa. The Western Romantic idea of nature and the traditional African holistic way of thinking seem to be made for one another.

Renowned African ethicist Bujo (2009), for example, begins his contribution on ecology in an anthology on African ethics as follows:

Africans are traditionally characterized by a holistic type of thinking and feeling. For them, there is no dichotomy between the sacred and the secular; they regard themselves in close relationship with the entire cosmos. Total realization of the self is impossible without peaceful co-existence with minerals, plants and animals. (p. 281)

In the next section, we will look at the place of the sacred in the context of African thinking concerning nature; here it is important to note that the African kind of holism is presented as a positive contribution to the ecological debate. In the same collection of essays, Ramose (2009:308) argues for 'ecology through ubuntu', the interconnectedness of particular humanity that is central in much African thought. And Murove (2009:315) argues that 'traditional African ethics recognizes the existential bond between people and the environment, the debt any generation owes its forebears and its consequent responsibility to posterity'. In many ways, the African world view and African theology are considered to be closer to nature than Euro-American theology is. This can be seen, for example, in its emphasis on holism and interconnectedness.

According to Orobator (2018:103f.), there is 'a dearth of published material in African theological research dealing with the significant question of ecology', yet, he notes that 'awareness is growing that the blend of culture and 
spirituality practiced on the continent provides additional resources for spiritually grounding ecological stewardship and responsibility'. Religions in Africa have been slow in responding to the ecological crisis, but, according to Orobator (2018:104), 'this delayed engagement is not for lack of available resources in our African tradition': we have 'much to learn from African Religion'. Orobator is referring to the sacrality of nature in Africa, but, in particular, to the focus in African thought in general on holism and interconnectedness.

Within a Western ecological context, holism is praised as an alternative to the tendency to destroy nature in the eagerness to 'cultivate' it, to make it culture. If we no longer consider nature as our opponent which we need to conquer, this might help to stop the annihilation of our ecosystem. If we recognise that we as human beings are merely small parts of this great Gaia-system, we might learn to treat nature better than we do now.

Holism in African thought developed in a very different context. Holism in an African context is not a response to a threatening ecological disaster, but it is and has been a fundamental feature of African thought systems for as long as people can remember. It is not a reaction to something; it is a given. It is the basic assumption in most African ways of thinking.

The Kenyan ecologist and Nobel Peace Prize winner Wangari Maathai describes the fundamental nature of holism in the African perception of nature as follows (in Orobator 2018):

Nature is not something set apart, with or against which we react. It's not a place we fear as something within which we might lose our humanity or, conversely, a place where we might gain perspective and simplicity away from the corruption and treachery of the court or the city. It is, instead, something within which human beings are enfolded. (p. 118)

Maathai decisively distinguishes the African conception of nature from its Western counterparts. Neither is nature a place to be tamed, turning it into a resource as a necessary step towards progress and civilisation, nor is nature conceptualised in opposition to the urban, industrial environment as sublime, mysterious and awe-inspiring, benevolent, comforting and redemptive. The non-Romantic conception of nature in the African context is very different. A holistic perspective on nature within an African framework is not a response to a degrading attitude towards nature, nor is it its Romanticist counterbalance, it is simply the way people think.

According to holism, humanity and nature exist on the same plane. Nature is not backward or holy in comparison to human beings, but human beings and nature together are one entity. Nature is not only something negative or an enemy, but it is also not something romantic and positive either. Whether nature is lower or higher is not a question that arises. If humanity and nature are one, then nature is not something that we should conquer and cultivate, nor should we revere and idealise it. It is simply what is, and we are a part - a natural part - of it.
The holism and interconnectedness of African thought precludes a Romanticist ecological awareness. Reverence for and worship of nature may be part and parcel of many African traditions, and this reverence and worship are most often practised in a particularly non-Romantic way. Romantic ideas of nature place humanity and nature over against one another, whereas African holistic conceptions view humanity to be fully a part of nature. Moreover, if humanity is fully a part of nature, then it is no problem to make use of nature as a resource, just like everything else in nature uses whatever it needs. If humanity and its activities are fully integrated parts of nature, then there is no difference between a farm, a game reserve and wilderness, or even an industrial area, because all of it is part of this one big entity called nature. A phrase like 'unpolluted wilderness' would not make sense, because pollution presupposes an intrusion from the outside, and from a holistic perspective, there is no outside.

If holistically there is no outside of nature, then nature cannot be 'pure', 'valuable', 'holy' or even 'backward', for this assumes a contrast with something that is not or less pure, valuable and so on, and there is no such thing like this in a holistic perspective.

When we look at the influential African theologian Magesa (2014:89), for example, following Augustine Shutte, he speaks about the earth as 'common property'. To speak about 'property' may not sound very ecological. Yet, the concept of property changes if there is no sharp contrast between humans and nature, but everything is interconnected: we own animals and land, but they own us just as well in different ways. This looser concept of property fits with the African ubuntu idea of common property as well: property relationships are never exclusive. Nature is a resource, just like we are a resource for nature - there is no either-or in this respect.

Describing African traditional values, Maillu (2012:38) emphasises that in African thought, humans and the world are made for one another - the earth is not merely a temporary abode on loan; therefore, humans have to be extra careful 'this is it' - but also: 'In this world, there are many empirical and spiritual secrets to help humans to live successfully'. So, the goal is again human success, and humanity may use the earth to achieve it. The anthropocentric nature of contemporary thought in the Anthropocene is present in Africa as well. But in a pre-industrial society, using whatever you find hidden in the world may be working well, because lions, viruses, rivers and so on, will use humans just as much.

Like values always and everywhere, African values arise from the circumstances in which people find themselves. And, as Ndegwah and Kroesen (2012:104) follow Robert Calderisi, the typical African communal values can be attributed to the 'harsh economic circumstances' on the continent. What is right in one situation does not need to be so in another situation. Ndegwah and Kroesen (2012:117) relate the response of a farmer seeing the 300 cattle of a 
pastoralist: 'If these were all mine, I would be slaughtering a cow every day'. The pastoralist disapprovingly notes: 'Then, by the end of the year, you would have none of the cows left'.

The kind of holism that belongs to traditional African thought fits traditional African circumstances. In those circumstances, humans, animals and other parts of nature can all freely try to take as much as they can. Within their system, they are all about equally powerful, and, most often, a workable balance would emerge. In a pre-industrial society, people do not need to be careful with nature, they do not need to take care of nature and nature can take care of itself. This is a kind of holism, but not a kind of holism that would fit contemporary circumstances.

The balance between humanity and nature in traditional African society is the result of (dire human) circumstances rather than of a holistic morality. Prozesky (2009) describes what happens when these circumstances change. He entitles his contribution to the anthology on African ethics 'Well-fed animals and starving babies', describing the apartheid situation with flourishing nature reserves and a poor black population. After apartheid:

Above all is the problem that, in a world of hard-hearted wealth, headed by the hard-hearted wealth of white South Africans, the only way many can quickly alleviate their poverty is by taking over nature reserves and forests. (p. 299)

Now we have 'humans surviving at the price of trees' (Prozesky 2009:300). The 'white, male lords of apartheid' were 'loving wild animals more than black babies', but nowadays in South Africa, 'the roles are reversed. The cattle will grow fat, the little herdboy will have shoes, but the antelope will be gone'; 'they do to trees, and all that lives among them, what the white man did to them' (Prozesky 2009:300). This is sad, but, according to Prozesky (2009:301), ' $[t]$ he poor damage the environment out of need, and it is not for the more fortunate to point the finger at their behaviour'. Nonetheless, Prozesky's observations show that African people do not have some natural, inborn ecological consciousness that they can teach the world.

African holism and the resulting conception of nature are not an antidote to the current global ecological crisis, because this kind of holism presupposed a kind of nature that was humanity's equal as a matter of fact. There might be parallels here with nature as a resource in the early modern context in the West, but not with the industrialised context that developed afterwards in which humanity overpowered nature. In the traditional African context, human beings could freely use nature as a resource, because nature would, in a manner of speaking, just as well use humanity as a resource. There was a natural balance.

If we look at the sermons we studied, we find many pastors speaking about nature as a resource to be used to further human success. Most of the applications that talk about nature in some way use the example of the farmer who prepares the fields, plants his crops and waits for a good harvest. The farmer displays important Christian values: he works hard, he hopes that the seeds will grow and he is faithful in looking after his crops. The focus in these examples is on the farmer, not on the natural environment that he is in. In one of these examples about a farmer, it is clear that the natural environment is particularly valuable if it is of service to humanity. Pastor Madalitso (10 May 2020) says:

This is harvest time, when farmers are harvesting their crops in their fields [...] I've seen farmers indeed harvesting ground nuts, harvesting sunflower, harvesting a number of different crops, but I've never seen a farmer harvesting weeds, only weeds, weeds, weeds, and preserving the weeds. I've never seen a farmer preserving the weeds, but when a farmer collects all the crops, the weeds remain in the field and the farmer may decide either to use that weed for manure or maybe to use that weed or burn it and indeed completely forget about it to make sure that the field is cleaned.

The plants are valuable as far as they are a resource for human survival. In a similar vein, another pastor speaks about leaders who should be hungry to provide a service in the same way that trees provide services.

The view that the natural world is a resource is most clear in this example from Pastor Bright (09 August 2020). He says in a sermon about Israel inhabiting the Promised Land:

Land is simply a place, an opportunity where you can acquire your wealth. [...] God is not only providing the ability, he is also providing the space, an opportunity for their wealth-creation. May you be encouraged, in the name of Jesus, that whatever land the Lord leads you into is a land where he will give you wealth, is a land where he has actively provided for you to acquire wealth.

The land in this sermon is not something to be protected or to be observed in awesome wonder, but it is an opportunity to be used by humanity. This might be a consequence of a holistic view on the unity of human and natural life, but it is still an anthropocentric view.

'God, remember us in your healing. Heal our land', is a prayer that is heard over and over again in the Zambian services. 'Heal the land' was a phrase that was used often in these sermons that were live-streamed mainly during the closure of churches during the COVID-19 pandemic. A slightly more extensive quote comes from Pastor Levison (24 May 2020):

Our prayer is that your visitation shall come upon our land Zambia, in the name of Jesus, and we shall see more of the glory of the Lord on the land of Zambia. Much more, that healing shall flow into this land, healing our bodies, healing our land, healing our economy, healing all our relationships.

In the above quote, it seems to be clear that the land needs healing because there is something wrong with its human inhabitants: their bodies, their economy and their relationships are affected by the COVID-19 pandemic. Again, this is a notably anthropocentric form of holism. 
We see that pastors, when they speak of 'heal the land', do not have nature in mind, but human well-being. Orobator (2018:103) names a chapter 'Healing the Earth, Healing Humanity', connecting ecological consciousness with the improvement of human life. He states that ' $[e]$ ssential to my argument is the conviction that healing the earth is primarily about healing humanity' (Orobator 2018:109). As holistically humanity is a part of the land, humans can freely strive for their own success, just like every other organism does naturally. There is no distinction between 'heal the land' and 'heal us humans' as we see in most sermons that we studied.

\section{Sacredness}

As laid out above, the Western Romanticist reappraisal of nature considered nature as sacred, yet in a very particular sense. The natural had already become separated from the supernatural, so nature could no longer be a direct representation of sacredness. Yet, in some ways, nature replaced the sacredness of the supernatural. It is no coincidence that the Gaia-hypothesis mentioned in the previous section is named after the Greek goddess that represents the earth. In the predominantly secularised Western-European setting that we are in, it has become commonplace to consider taking a walk in nature as a valid alternative to worshiping in church. Meditation, time to reflect, closeness to God and adoration of the divine used to be associated with churches, but they have more and more found their natural habitat in visits to nature. Churches used to offer a space away from the busyness and ambiguity of daily life. In a Western context, nature has become that place, to escape for a while the pollution of human civilisation.

Nature in the West has been adorned with aspects of the sacred, but, as mentioned above, only with its positive aspects. Rudolph Otto famously defined the sacred as a mystery that evokes both trembling and fascination. Nature in the West only inspires fascination. It is more awe-inspiring than terrifying, more majestic than dangerous. Like the epigraph of this article expressed, nature is something wonderful to enjoy and admire and be grateful for. This Romanticist, exclusively positive valuation of nature, however, is an exception in Africa.

For example, during our six years in Zambia, we never heard of any local taking a stroll in nature or admiring the landscape. The few times that they visited the beautiful nature reserves in the country, they photographed themselves in front of the sign of the park and their accommodations, but we hardly ever saw pictures of animals or landscapes. This illustrates that in daily life in Africa, the rosy kind of sacredness that has become an important aspect of the idea of nature in the West is often almost absent.

On the other hand, however, African traditional thought considered nature as sacred. The influence of Western ideas brought about the loss of this African sense of sacredness and caused ecological destruction, according to Wangari Maathai. Speaking about the negative influence of European missionaries, she (Orobator 2018:120) states, '[h]allowed landscapes lost their sacredness and were exploited as local people became insensitive to the destruction, accepting it as a sign of progress'. Orobator (2018:106) laments how holy rivers have become pitiable polluted streams: '[w]orshipers still come by night, but during the day its banks hold the busiest carwash stations in town'. As natural elements like rivers are no longer hallowed, they have become abused and polluted.

But in this context, it is important to understand what it meant by the 'hallowedness' of the landscape: it was not hallowed in a romantic sense, but in the pragmatic, animistic sense of being respected as a force, one has to reckon with a bunch of fellow spirits as equals. Maybe statements about the sacredness of nature are often interpreted as identifying African traditional beliefs with Romanticist ecology: 'hallowed landscapes' in the African sense is easily confused with the language of Romanticist ecological discourse, but the African conception of sacredness connected to nature is of a very different kind.

Orobator (2018:123) narrates how an African animist asks forgiveness of plants before cutting them, asking them to help serve the purpose for which they are cut down. Hunters explain to their prey that their family needs food. Drum makers explain to the tree that the people need joy, and so on. Orobator (2018:125) concludes that we are 'ecological siblings with all of nature' and this 'makes it personal: it entails an abiding bond of interpersonal relationships, mutuality, and interdependence'.

Likewise, Magesa (2014:90) speaks about the spirits of the primary owners of everything in nature. This reflects a kind of mutuality: we use the river, but if we dig a hole, the river may use our work to find new ways. Rivers, animals, plants and rocks are not merely objects but animated, part of the cosmic community. Magesa (2014:171) quotes Mark Hathaway and Leonardo Boff: 'A plant, then, is not just something before me - it is a resonance, a symbol, and a value within me'. According to Magesa (2014:171), this implies a natural 'respect for other-than-human modes of existence' in that it perceives the 'presence of the human spirit in animals, plants and other beings'.

Nature consists of fellow spirits just like humans. On the one hand, this is more respectful than a blunt modern perspective that treats nature as an object to conquer or a property. On the other hand, it means that we can make deals with nature as equals. African animism treats natural entities as equals. It is no problem to try to get as much out of the other as you can. From a different angle, factually, in most animist societies, humans and their natural counterparts were equals. If both tried to get as much out of each other as they could, a balance would remain. In industrial societies, humans have 
factually become too skilled to reach such a balance. Humans and nature are not equals conceptually, but not equals factually either: humans are able to destroy nature.

Magesa (2014:175) speaks about peaceful coexistence between humans and nature in traditional African society, but rather than the result of a moral choice on the side of humans, this was because both sides were equals in power and skill to use one another, like a kind of Cold War situation.

In the 1970s, the missionary organisation Missio built a chapel in Germany based on what they considered to be 'the understanding of the forest of the Achewa tribe in Malawi' (in Bujo 2009):

The tropical forest is a place of abundant life; here nature, i.e. plants and animals, finds appropriate conditions to grow and multiply. [... It is] the place where God bestows the gift of life on humans as well as animals and plants. [...] In many often hidden details, nature is visualized as it was originally created by God and how he wants it conserved: wild lianas [...] animals [...] as friends and partners of humankind $[\ldots]$ evergreen plants in the church confirm the sacred virgin forest as a place of life. The fundamental unity of the human person with the cosmos becomes apparent here. (p. 283f.)

We do not recognise this picture of a Chewa attitude towards nature at all. This is an example of a Romanticist misinterpretation of nature and its sacredness in Africa. In the African context, nature is hardly ever considered a friendly partner, nature is terrifying and dangerous. It is the bush where the spirit world is close, too close for comfort.

Spiritual attacks are a topic in the Zambian sermons, some even going as far as calling the coronavirus a disease that has originated in the spirit world, but the Zambian sermons do not speak about the particular proximity of the spiritual world if one ventures beyond populated spaces. They do, however, portray the natural world as a dangerous place. Magesa (2014:95) notes that in the African context, God's immanence is emphasised over and above his transcendence: 'sometimes people wish that spirits were not so near or so immanent'. The village is a safe place, whereas in the bush, the spirit world is far too near. Nature is sacred, but especially in its terrifying way rather than as something majestic, desirable or aweinspiring. The contrast between village and bush is closer to the modern contrast between culture and nature than to the Romanticist contrast between the polluted, deprived human world and its glorious, hallowed natural counterpart. Nature is not a pure and virginal, but a counterpart with whom humanity is struggling. If the situation is not one of war, it is one of Cold War. Nature is sacred, but because it is sacred, it is not a place to take a stroll and it is not a place of quiet and comfort to revive your spirituality. Anthropologist Morris (1995) labels this view of nature a 'unity-in-opposition'.

In the traditional African setting, nature is sacred in the sense of terrifying and dangerous. We find this in the sermons in Zambia as well. Next to examples of nature as a resource and the heal-the-land prayers mentioned in the previous section, nature as a metaphor for challenges was how nature was used most often in the sermons. When challenges come our way, such as the COVID-19 pandemic, we are said to be 'in a storm', 'in the bush', 'in the wilderness', 'in a dry season' or 'climbing a mountain'. In all of these examples, an element of nature is used as a metaphor for difficulties that one may encounter in life. Whilst pastors used these metaphors of the natural world mainly for challenging circumstances, metaphors from nature for positive situations were almost absent. The only metaphor that was mentioned several times was 'green pastures' for a promising and supportive environment. But this metaphor comes directly from the Bible and is therefore less significant to get an insight into the African language of faith concerning nature. All in all, the pastors seem to experience the natural world mainly as a challenge and a source of struggle.

\section{Conclusion}

Something has gone terribly wrong with our natural environment. We are in the middle of an ecological crisis. If we want to save the earth - and with it humanity - we need to radically reconfigure our relationship with our ecoenvironment. In many ways, the African world view and African theology are closer to nature than Euro-American theology is. This can be seen, for example, in its emphasis on holism and interconnectedness, and its inclination to consider all natural objects to be inhabited by the spirit world. This article argued, however, that this closeness to nature should not be confused with a Romantic reverence for nature.

Since the 19th century, Romanticism has been very influential in the Euro-American idea of nature. Nature came to be seen as something that is both good and valuable in itself. The idea of nature that is dominant in African ways of thinking is very different: nature is seen as potentially threatening and, at best, ambivalent; and respect for nature and living in balance with nature is judged by the extent to which it helps humans to live successfully.

The rooted and timeless aspects of the countryside perceived in the period of Romanticism also imply a connection with an inherited knowledge that is lost to the modern city dwellers (Hutton 1999:117). We should be careful not to look at African traditions for new solutions for our environmental problems out of such a Romantic conception that these traditions have preserved knowledge that we have lost. Let us accept these ideas on their merits, and not just because they come from Africa.

In this article, a theological and philosophical clarification of the African non-Romantic idea of nature is combined with qualitative anthropological analysis of the way Zambian pastors speak about nature in their sermons. These two approaches together bring out the oftenmisinterpreted non-Romantic idea of nature in African theology. This shows how the meaning of holism and sacredness in African settings differs from the meaning of these concepts in Western eco-theological contexts. Thereby, important confusions in the field of eco-theology are untangled. 


\section{Acknowledgements}

J.K.K. wrote this article as Postdoctoral Fellow at the Department of Religious Studies at the Faculty of Theology and Religion at the University of Pretoria. H.K. wrote this article as Research Associate in the programme 'Understanding Reality' at the Department of Systematic and Historical Studies at the Faculty of Theology and Religion at the University of Pretoria.

\section{Competing interests}

The authors declare that they have no financial or personal relationships that may have inappropriately influenced them in writing this article.

\section{Authors' contributions}

Both authors contributed equally to the article. H.K.'s contribution focussed on the theological and philosophical clarification, while J.K.K. contributed towards the anthropological analysis.

\section{Ethical considerations}

This article followed all ethical standards for research without direct contact with human or animal subjects.

\section{Funding information}

This research received no specific grant from any funding agency in the public, commercial or not-for-profit sectors.

\section{Data availability}

Data sharing is not applicable to this article as no new data were created or analysed in this study.

\section{Disclaimer}

The views and opinions expressed in this article are those of the authors and do not necessarily reflect the official policy or position of any affiliated agency of the authors.

\section{References}

Bankoff, G., 2001, 'Rendering the world unsafe: “Vulnerability" as Western discourse', Disasters 25(1), 19-35. https://doi.org/10.1111/1467-7717.00159

Bewell, A., 2017, Natures in translation: Romanticism and colonial natural history, Johns Hopkins University Press, Baltimore, MD

Buitendag, J., 2019, 'Jy moet die aarde liefhê soos jouself', LitNet Akademies 16(3) 305-320.

Bujo, B., 2009, 'Ecology and ethical responsibility from an African perspective', in M.F. Murove (ed.), African ethics: An anthology of comparative and applied ethics, pp. 281-297, University of KwaZulu-Natal Press, Scottsville, VA

Chibuye, L. \& Buitendag, J., 2020, 'The indiginisation of eco-theology: The case of the Lamba people of the Copperbelt in Zambia', HTS Teologiese Studies/Theological Studies 76(1), a6067. https://doi.org/10.4102/hts.v76i1.6067

Descola, P., 1996, 'Constructing natures: Symbolic ecology and social practice', in P. Descola and G. Pálsson (eds.), Nature and society: Anthropological perspectives, pp. 82-102, Routledge, London.

Giddens, A., 2009, Sociology, 6th edn., Wiley India, New Delhi.

Hutton, R., 1999, The Triumph of the moon: A history of modern Pagan Witchcraft, Oxford University Press, Oxford.

Knoetze, J.J., 2021, 'Reformed theology in dialogue with a spirituality of creation within the context of religious pluralism in Africa', HTS Teologiese Studies/ Theological Studies 77(4), a6336. https://doi.org/10.4102/hts.v77i4.6336

Kroesbergen, H., 2020, 'Religious diversity, ecology and grammar', HTS Teologiese Studies/Theological Studies 76(1), a6064. https://doi.org/10.4102/hts.v76i1.6064

Magesa, L., 2014, What is not sacred? African spirituality, Action Publishers, Nairobi.

Maillu, D.M., 2012, 'The core of African traditional values', in J.N.K. Mugambi \& D.W. Lutz (eds.), Applied ethics in religion and culture: Contextual and global challenges, pp. 29-46, Action Publishers, Nairobi.

Maris, V., 2018, La Part Sauvage du Monde: Penser la Nature dans l'Antropocène, Éditions du Seuil, Paris.

McKibben, B., 2007, The end of nature, Random House Trade Paperbacks, New York, NY.

Morris, B., 1995, "Woodland and village: Reflections on the "animal estate" in rural Malawi', The Journal of the Royal Anthropological Institute 1(2), 301-315. https:// doi.org/10.2307/3034690

Murove, M.F., 2009, 'An African environmental ethic based on the concepts of Ukama and Ubuntu', in M.F. Murove (ed.), African ethics: An anthology of comparative and applied ethics, pp. 315-332, University of KwaZulu-Natal Press, Scottsville, VA.

Ndegwa, D.J. \& Kroesen, O.J., 2012, 'The ethics of technology, culture and environment', in J.N.K. Mugambi \& D.W. Lutz (eds.), Applied ethics in religion and culture: Contextual and global challenges, pp. 97-120, Action Publishers, Nairobi.

Orobator, A.E., 2018, Religion and faith in Africa: Confessions of an animist, Orbis Books, Maryknoll, NY.

Prozesky, M.H., 2009, 'Well-fed animals and starving babies: Environmental and developmental challenges from process and African perspectives', in M.F. Murove (ed.), African ethics: An anthology of comparative and applied ethics, pp. 298-307, University of KwaZulu-Natal Press, Scottsville, VA.

Ramose, M.B., 2009, 'Ecology through Ubuntu', in M.F. Murove (ed.), African ethics: An anthology of comparative and applied ethics, pp. 308-314, University of KwaZulu-Natal Press, Scottsville, VA.

Thomas, K., 1984, Man and the natural world: Changing attitudes in England 15001800 , Penguin Books, London.

Williams, R., 2015, Keywords: A vocabulary of culture and society, Oxford University Press, New York, NY. 